Article

\title{
Gender and Public Space: Mapping Palimpsests of Art, Design, and Agency in Shahbag, Dhaka
}

\author{
Salma Begum ${ }^{1, *}$, Jinat Hossain ${ }^{2}$ and Jeroen Stevens ${ }^{1}$ \\ ${ }^{1}$ Department of Architecture, KU Leuven, Belgium; E-Mails: salma.begum@kuleuven.be (S.B.), \\ jeroen.stevens@kuleuven.be (J.S.) \\ ${ }^{2}$ Department of Earth and Environmental Sciences, KU Leuven, Belgium; E-Mail: jinat.hossain@kuleuven.be \\ * Corresponding author
}

Submitted: 14 April 2021 | Accepted: 22 July 2021 | Published: 30 November 2021

\begin{abstract}
Public space is an essential social infrastructure for the continuous negotiation of city life and democracy because it offers (ideally) an interactive platform for people from diverse social and cultural backgrounds and the forms of public life they cherish. This contribution inquires how public space's design and materiality play a fundamental role in popular struggles for social justice. By focusing on the differentiated access of women to public space, the role of gender in its design, and appropriation through a feminist intersectionality lens, this article aims to understand better the complex interplay between urban space and its non-human material agency vis-à-vis citizen mobilizations, movements, and socially engaged art interventions. Drawing from extensive participant observation and spatial analysis, the exemplary public space of Shahbag Chattwar (a public square/plaza) will shed light on the "gendered spatiality" of pivotal popular mobilizations and reclamations from the historical momentum of the 1952 language movement, over the 2013 contemporary Shahbag protests, and to the 2020 anti-metro rail protests at the Dhaka University campus. Analyzing urban space as a "palimpsest," this research reflects on both historic and ongoing scenarios of popular protests as they repeatedly occupy public space and leave spatial traces through spatial design and art. In sum, the article seeks to gain insight into public space as a principal site of contestation and negotiation of juxtaposed layers of gendered dynamics, civil rights, secularism, and fundamentalism.
\end{abstract}

\section{Keywords}

art and architecture; gender; palimpsest; public space; Shahbag

Issue

This article is a part of the issue "Art and Design for Social Inclusion in the Public Sphere" edited by Karin Hannes (KU Leuven, Belgium).

(C) 2021 by the authors; licensee Cogitatio (Lisbon, Portugal). This article is licensed under a Creative Commons Attribution 4.0 International License (CC BY).

\section{Introduction}

Cities, and public space in particular, are palimpsests of history (Corboz, 1983). As urbanization unwinds, each layer of historical sedimentation deposits spatial "inscriptions" in the territory, intricately intertwining with everyday engagements and public concerns of epochs. The continuous production and reproduction of public space are in such light closely bound up with evolving social paradigms and patterns of everyday life. The metaphor of the palimpsest is thus help- ful to unravel how cities are constantly transforming and complexifying environments. In that process of relentless change, urban development removes, re-inscribes, and superimposes "new" spatial adaptations on top and amidst of existing configurations. Not each layer remains therein permanently visible. But the gradual accumulation of intermingled traces intricately links places to multiple memories and identities, which eventually appear as complex cultural landscapes. Rendering public space as such a palimpsest, by analogy, emphasizes historical precedents, architectural influences, culturally practiced 
traditions, subsequential political ecologies, political contestations, as well as changing gender roles. Each city has its own distinct reality and complex array of agents involved in its conception and development. Dhaka city's 400-year history is not different, and different political cycles have produced a rich public domain imbued with diversified cultural and social uses and meanings.

Public space can thus not only be understood as open, accessible space, "free" for the diverse urban public to use, but also a political trope where societal conflict and contestation play out. As it supposedly does not belong to any group or individual, it pertains to "the public" in all its diversity and corresponding disagreement. These spaces thus inevitably articulate the contestation and disputes that riddle "the public" and the city at large. Therefore, public space is not only the emblematic stage but also the perpetually contested outcome of "ordinary" everyday practices, and "extraordinary" protests, riots, or revolts that seek to shift the status quo. Not least in Bangladesh, gender plays a crucial role in shaping such everyday practices. These "gendered activities" in public space are fluid, and constantly transforming over time. They are not only shaped and reshaped through everyday habits and customs, but also administered by state legislations and changing cultural and social norms at different scales (Kern, 2020). Such fluidity adds complexity to the understanding of the city and its public space as a palimpsestic result of citizen involvements, interactions, changing actions, and engagements with space (Beebeejaun, 2017; Bondi, 1998).

Women's presence in public space is crisscrossing two contrasting scenarios in Dhaka, Bangladesh, where modernity and traditional religious norms walk side by side (White, 2012). State authority is contested, especially given the recent blend of secularism and religion in the constitution (Salehin, 2018). Against this religiouspolitical structure, broader national and global feminist agendas are essential to understand the constant transformation and negotiation of "gendered space" in Dhaka, where public space is traditionally masculine. Women's presence and involvement in Dhaka's public space are conventionally limited. However, three significant events triggered women's appearance in public space: (a) the high number of female enrolments in primary and secondary schools, (b) significant female participation in the ready-made garment industry, and (c) the increasing number of women involved in public, private, and local government services through gender quotas (Nazneen, 2017; Panday, 2008). All these resulted from several national policy initiatives and the global feminist movement.

The constitution of Bangladesh ensures nondiscrimination under various articles, such as Article 27, which designates all citizens with equal protection as a fundamental right, and Articles 28 and 29, which disallow discrimination on the grounds of religion, sex, race, caste, and the like (Constitution of the People's Republic of Bangladesh, 1972). Beyond the state's commitment, global feminist agendas and conventions were very influential. As a state, Bangladesh has committed to the world community by signing and ratifying many international mandates, treaties and conventions that avowedly guarantee gender-equal provision for all, irrespective of sex or religious regulations, such as Article 7 of the Universal Declaration of Human Rights, the Convention on the Elimination of All Forms of Discrimination, the International Covenant on Economic, Social and Cultural Rights, and the Beijing Platform for Action. However, despite these regulatory initiatives, women's presence in public space continued to be challenged by conservative political, religious, and societal norms, adding tensions and contestation to public space use, form, and meaning. Against this backdrop, the following historical analysis will investigate the spatial evolution and episodic sequence of events on Shahbag (Figure 1), Dhaka, as a political arena. The Shahbag area lies between the new Dhaka in the north and the old Dhaka in the south, where Shahbag Chattwar is a vibrant cultural corridor (Figures 1 and 2) brimmed with diverse everyday practices, Bengali festivals, and protests. The place witnessed a rigorous urban makeover, however, without diminishing its lively spirit. At present, it is not only a prime hub for institutions, architectural edifices, cultural agglomerations, and a prime public transport hub but also a foremost political hotbed in the city's public realm.

A feminist intersectionality lens is helpful to understand the gender-differentiated access to public space in Dhaka. Crenshaw (1989) presented the term "intersectionality" to investigate the intertwining systems of subjugation and metamorphosis in specific contexts, elaborating lived and embodied experiences (Collins, 1990; Collins \& Bilge, 2016; Crenshaw, 1991). Intersectionality draws attention to the intersections and their impact on different axes of identity (e.g., gender, sexuality, class, caste, race, age, education, status, ownership, and rights) that is unexplainable with single-identity analysis (Crenshaw, 1991; Nightingale, 2011). Although black and postcolonial feminist scholars conceptualized it, intersectionality is relevant for many societies worldwide (Sultana, 2020; Yuval-Davis, 2006). In the context of Dhaka, Sultana (2020) highlighted gender, class, and migration as particularly pressing axes of social difference and oppression. This case of Shahbag will further illustrate how the socio-historical construction and lived experience of urban lives, mobility and movements are influenced by the complex network of intersectional socio-spatial and gender differences. This way, the case study will also contribute to the analysis of feminist geographers who stress how the experiences, lives and events of urbanization, and urban spaces are significantly influenced by gender (Chant \& Mcllwaine, 2016; Doshi, 2017; Peake, 2016). In this line, the role of "gendered space" will be examined to understand the complex interplay of gender and identity in mobilization, movements, and protests that seek to shape and re-shape public space. 


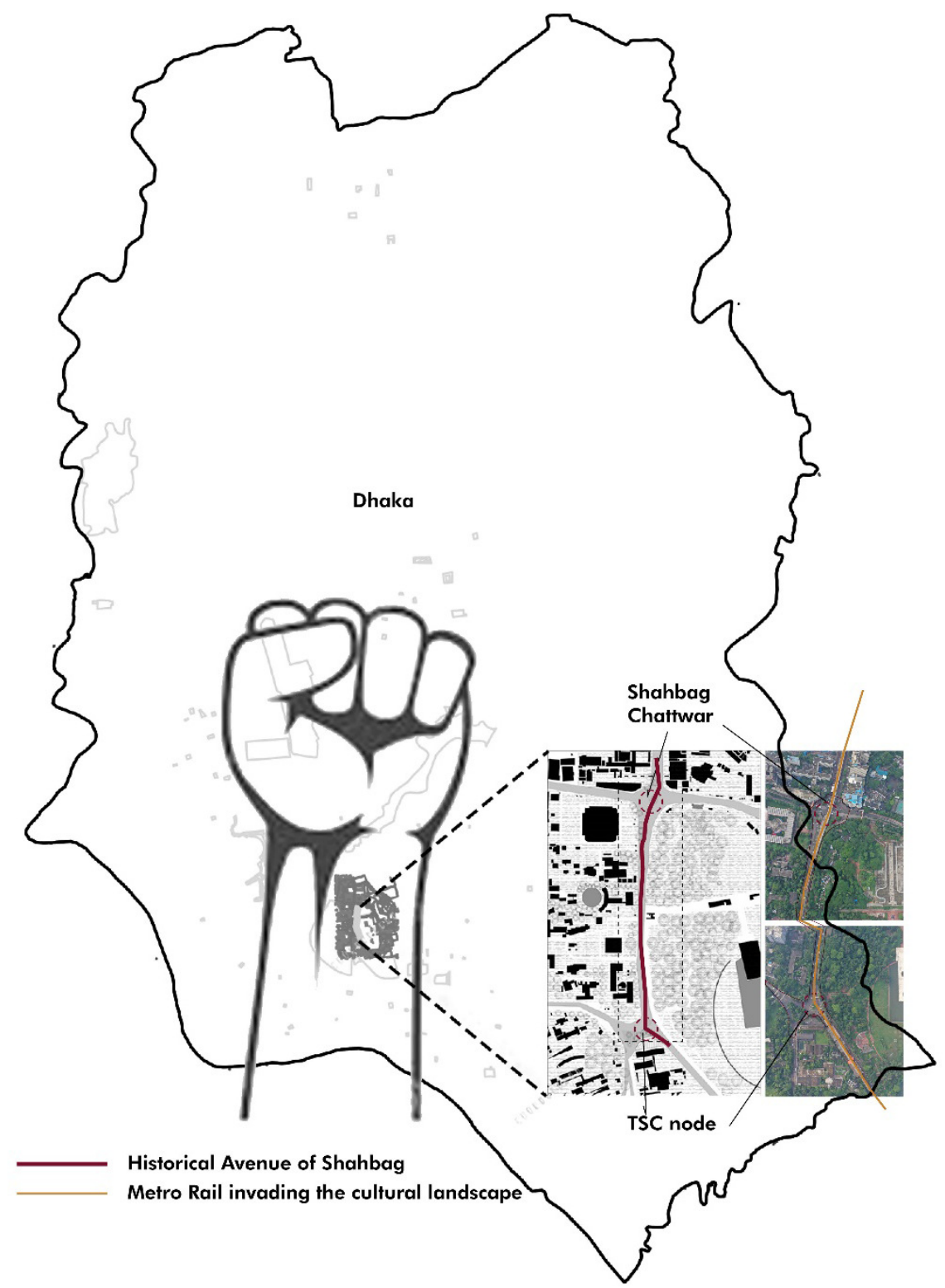

Figure 1. Shahbag area and historic avenue as palimpsest in the context of Dhaka. Figure developed by author Salma Begum.

\section{Material and Methods}

This study is based on an extensive literature survey, participant observation, and field experience followed by cartography. Secondary literature survey included scientific and popular pieces of literature (local press, history books, archival data, other reports, etc.). The first author, as an architect, gained everyday experiences through designing various architectural projects, participating in, and organizing various events between 2004 and 2018 around the Dhaka University precinct. The second author has gained on-site life experiences during her study at Dhaka University between 2005 and 2011, including active participation in different social and cultural movements during that time and beyond. For example, she actively participated in the Shahbag movement in 2013. Maps of the selected periods have been collected from primary and secondary sources and were analyzed as a series of collected events. The cartographic explorations are part of the ongoing $\mathrm{PhD}$ research of the first author.

For this research, five maps of Ramna corresponding to specific urbanization periods (map of 1859, map of 1905, map of 1952, map of 1975, and Dhaka GIS map of 2015) are deployed to illustrate the changing spatial and political ecology of the Shahbag area. The objective is to understand the transformative process of the landscape of the present-day public space Shahbag Chattwar. The study investigates the metamorphosis of Shahbag as it was shaped by specific design intentions, art interventions and gender dynamics. The analysis illustrates a series of cartographic drawings that juxtapose multiple 
sources of information and typographies - referencing a historical route of Shahbag as a palimpsest of protest, processions, and festivals through the choreography of a landscape that unfolds multiple events and agents, such as an avenue intended for cars which became occupied by people, or green spaces meant for pleasure which amplified riots and revolts.

\section{Shahbag as Palimpsest}

Historically, Dhaka's urban anatomy changed hand in hand with multiple political regimes. Due to its geographical location, it has attracted many and miscellaneous settlers (Begum, 2020). As human presence increased, different power regimes imprinted lasting traces in the city's spatial form, and its public space in particular. The city played its role as capital of Bengal from 1610 to 1757 , under the Mughals. It was during this era that the present-day Shahbag Chattwar was developed as a pleasure garden outside the city core and became known as Bagh-e-Badshahi or Shahbag ("garden of the king"; Begum, 2018).
The landscape of Shahbag has been re-structured and re-formed through overlapping episodes of events, including both planned interventions and more spontaneous appropriations of space. The meanings attributed to this place changed accordingly, and altered several times in terms of experience, embodied memories, public appreciation, and political connotation. As the physical materiality of Shahbag changed over time from a garden to an urban platform, it can be recognized as a palimpsest of history, in which architectural and semiotic traces were left by multiple manifestations, political agendas, war, and events that subsequently and simultaneously occupied the site across different timeframes. The palimpsest metaphor (Figure 2) alludes to the links between these different timeframes, and the resulting multitude of modifications, overlapping events, and levels of interconnectedness, revealing the current urban landscape as a juxtaposition of different episodes. The metaphor also allows recognizing how the historical avenue of Shahbag relates to popular protests and struggles for social inclusion.

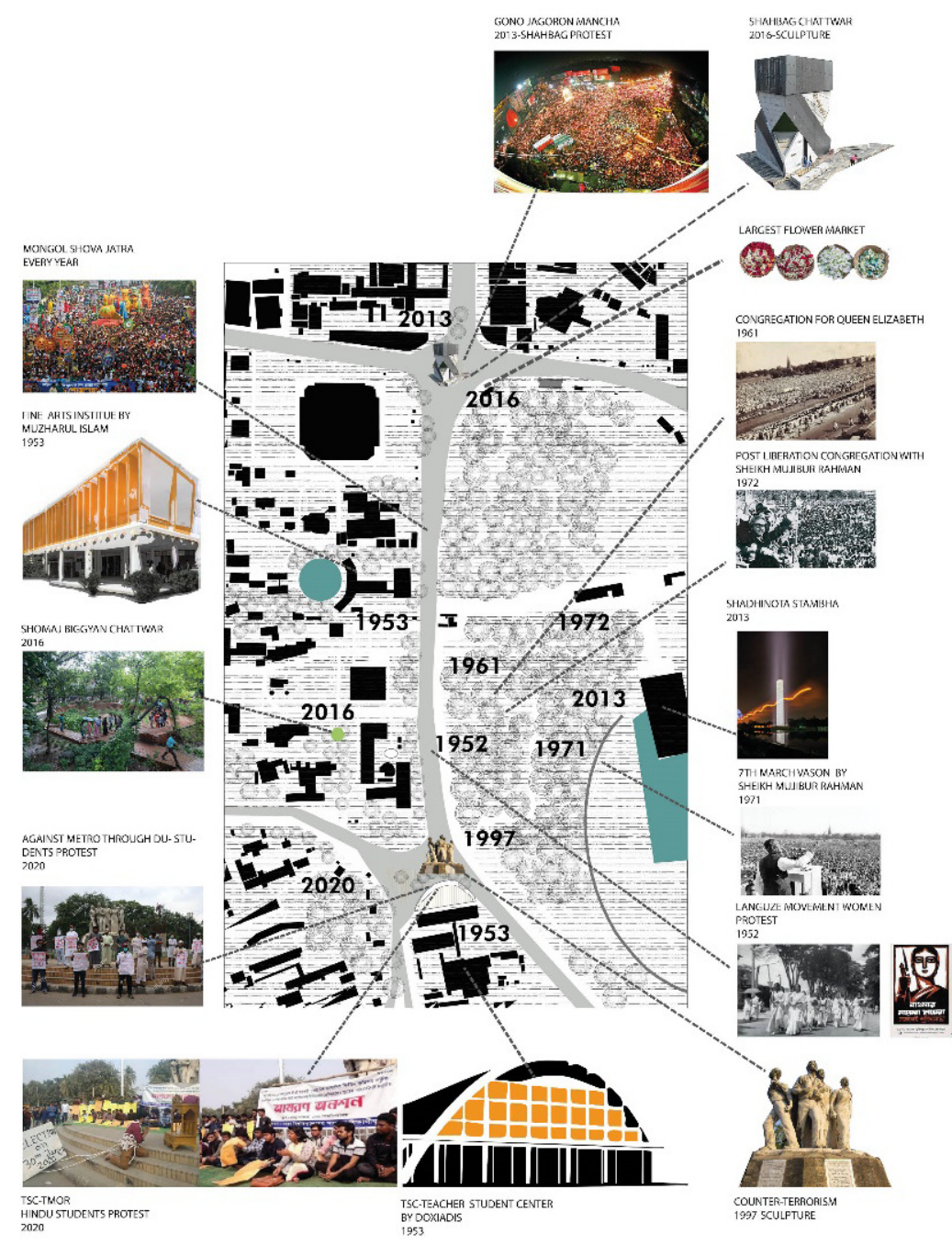

Figure 2. Evolution of Shahbag Chattwar as a ground of events and protest. Figure developed by author Salma Begum. 


\subsection{Shahbag as Bagh-e Badshahi Through a Mughal Lens}

Dhaka's political history can be traced back to 1200 and the pre-Mughal era. Afterwards, the city served as the country's capital from 1610 to 1757 under the Mughals. During the Mughal period, Shahbag was structured by a constellation of green and vacant open spaces (Figure 3). The constellation of green spaces consists of present-day Shahbag, Ramna park, and Suhrawardi Udyan flanked by Segun forest on the northeast side. The area marked the last limit of the city with the Ramna gate. The mixed-use urban core was south of Ramna, connected by three main muddy roads confined between the Buriganga River and the Dulai Khal Canal. The past Shahbag area shows a strong presence of water bodies, with ponds as a distinct component in the territory. Landscape elements in fact structured most of the Shahbag area and remained the most significant spatial feature characterizing the Mughal period. While most of the area was considered part of the landscape, the interior of a house and women's presence in public space was largely influenced by Islamic practice. Women usually maintained a private life inside the house. In contrast to men, the "inclusion" of women in public space during this political period was rather restricted under colonial subjugation. This period alludes to the first episode of Shahbag palimpsest, marked by landscape elements and controlled by religious norms in view of gender dynamics in public space.

\subsection{Shahbag as Ramna Racecourse as a Colonial Outcome 1905-1975}

\subsubsection{Colonial Imprints on the Cultural Landscape 1905-1952}

Dhaka later emerged as the capital of Bengal, East Pakistan, and Bangladesh throughout its history. Still, it left strong development imprints in two specific episodes during the colonial era in 1905 and the east-Pakistan era in 1947. As the capital of Eastern Bengal and Assam in 1905 , it started to flourish. Its designation as the capital of East Pakistan in 1947 marked a pivotal historical shift. Soon after the East India Company took over, Dhaka began to transform drastically. The significant changes observed in the Shahbag area included the mutation of the garden to the British's racecourse in 1825, new villas by the Nawabs in 1840, and the implementation

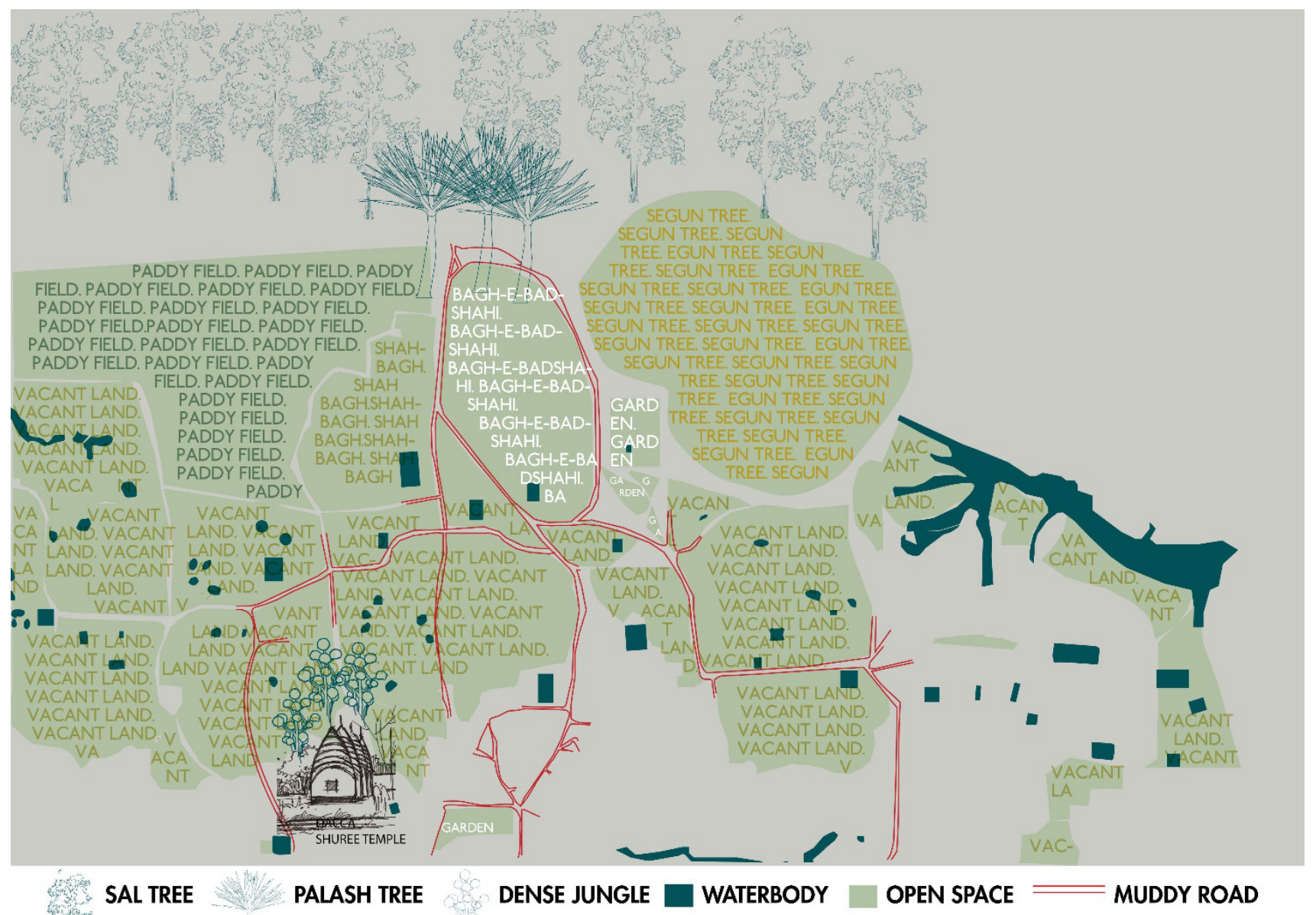

Figure 3. Bagh-e-Badshahi, the pleasure garden outside the historic city core during the Mughal period. Figure developed by author Salma Begum. 
of a muddy road for elephant movement that later influenced the development of Shahbag Chattwar, a new civil station, and the introduction of a railway. The civil station, consisting of the Old High Court buildings, Secretariat, and Town Hall (Dhaka Hall), formed the city's core and significantly changed the urban morphology. Later, the civil station transformed into an educational institution, and in 1921 the area became Dhaka University. The emergence of Dhaka University in 1921 played a substantial role in women's presence in the area. The first female student at Dhaka University was Lilabati Nag, a pioneer who formally joined the university in 1923. She was a female activist and organizer with academic excellence who established an all-women club named Dipali committed to women emancipation (Siddiqua, 2017). Muslim women joined the university later than Hindus. Begum Faziltunnesa was the first Muslim female student at Dhaka University and graduated in 1928 (Siddiqua, 2017). Eventually, Shahbag's educational role in the city appeared to create a secular ground for students also.

The Bagh-e-Badshahi attained a new form of public space and was renamed as Ramna racecourse.
It brought a significant change in gender-biased appropriation. The colonial period saw women's formal presence in public space as a violation of religious idioms (Figure 4). Women were deprived of permission to public life and pursue economic occupations during the Mughal period (Lal, 2003). This period also saw public discourse around women's rights and roles in the Bengali-Muslim society primarily shaped by male perspectives, including a minority of urban educated middleclass and upper-class women (Lal, 2003; Nazneen, 2017). The colonial episode of Shahbag thus experienced multiple sequences of significant changes in physicality, morphology, and women's rights to public space as a palimpsestic layer of urban history.

\subsubsection{Colonial Civil Station as a Line of Protest During} the Liberation War (1952-1965)

In the post-colonial period after 1947, with the initiation of another political era, Dhaka was re-structured according to modern planning and development idioms (Begum, 2018). In parallel, Ramna was continuously modified and re-constituted by public appropriations. By the

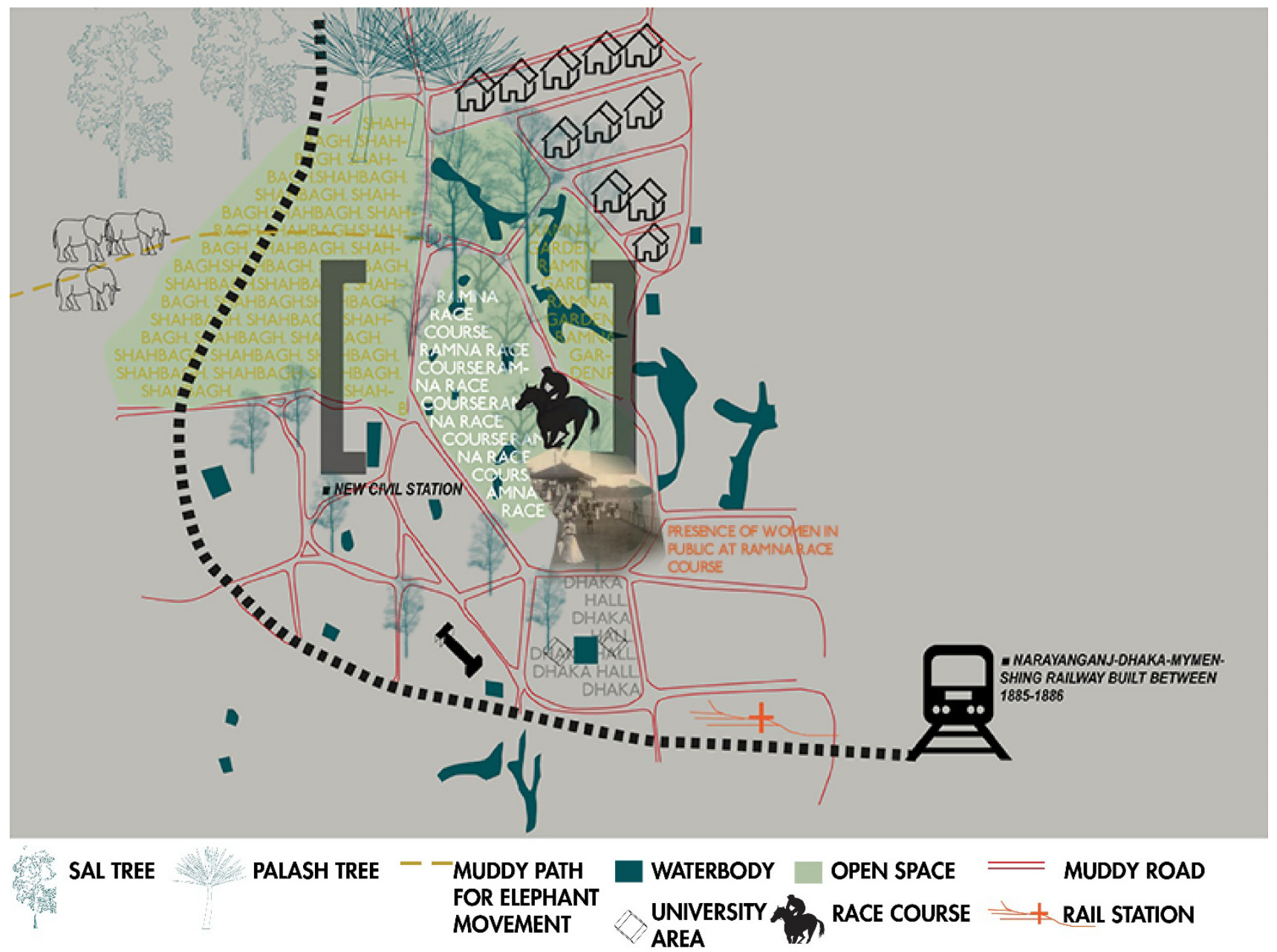

Figure 4. Shahbag as a network of gardens known as Ramna with the new colonial railway, civil station, and racecourse begin to see the presence of women in public. Figure developed by author Salma Begum. 
1950's, it was divided into two areas: the Ramna Park and the racecourse. In 1951, the East Pakistan Government captured the Shahbag garden from the Nawabs and part of it was given to Dhaka University. In the development process, the Segun forest in Segunbagicha area was cleared, and urbanization took over. This period set off Bengali modernism that appeared through the design of the Fine Arts Institute. The Fine Art Institute, commonly known as Charukola, (Figures 5 and 6), is a pioneering modernist icon in Dhaka, Bangladesh, designed by architect Muzharul Islam who left his legacy in Bangladesh's architectural practice. He was a genuine modernist and greatly influenced by two of his teachers, Ross and Hayden, who taught him to be both a Bengali and a cosmopolitan man. Besides being an architect, Muzharul was an activist and politician. His idea for the Fine Art Institute was to make a place for all, irrespective of gender, age, class, etc. He struggled to establish Bengali modernism free from superficial regionalism. Its climateresponsive design harmoniously blends natural logic with modern architecture. This project played a remarkable role in Dhaka's advancement of social inclusion since the 1950s. At present, this project is part of the everyday modernity of Dhaka people, hosting diversified cultural, educational events throughout the year.

While emerging, the university project followed the area's essence without denying nature, keeping all the trees as they were. A pavilion on pilotis (Figure 6) invites people to the famous campus, which has evolved from the Mughal Pavilion but with a modernist strain. The use of locally produced brickwork attributed it with a regional character and emphasized the experience of natural light, shadow, and wind. Furthermore, its architecture showed a strong devotion to history, place, topography, materiality, local construction methods, and socio-economic context without falling into vernacular provincialism. If anything, Islam's design reflects a modernism tailor-fit to Dhaka rather than attempting to be global or universal. Another masterpiece from the same architect, the public library (Figure 5), presently known as Dhaka University library, was constructed in the same area and started facilitating multiple events. Thus, the university area, and the Ayub Khan Avenue (present-day Shahbag Road) in particular, was promoted as an axis of movement with the construction of the Teacher-Student Centre in 1961 by Doxiadis. The Ayub

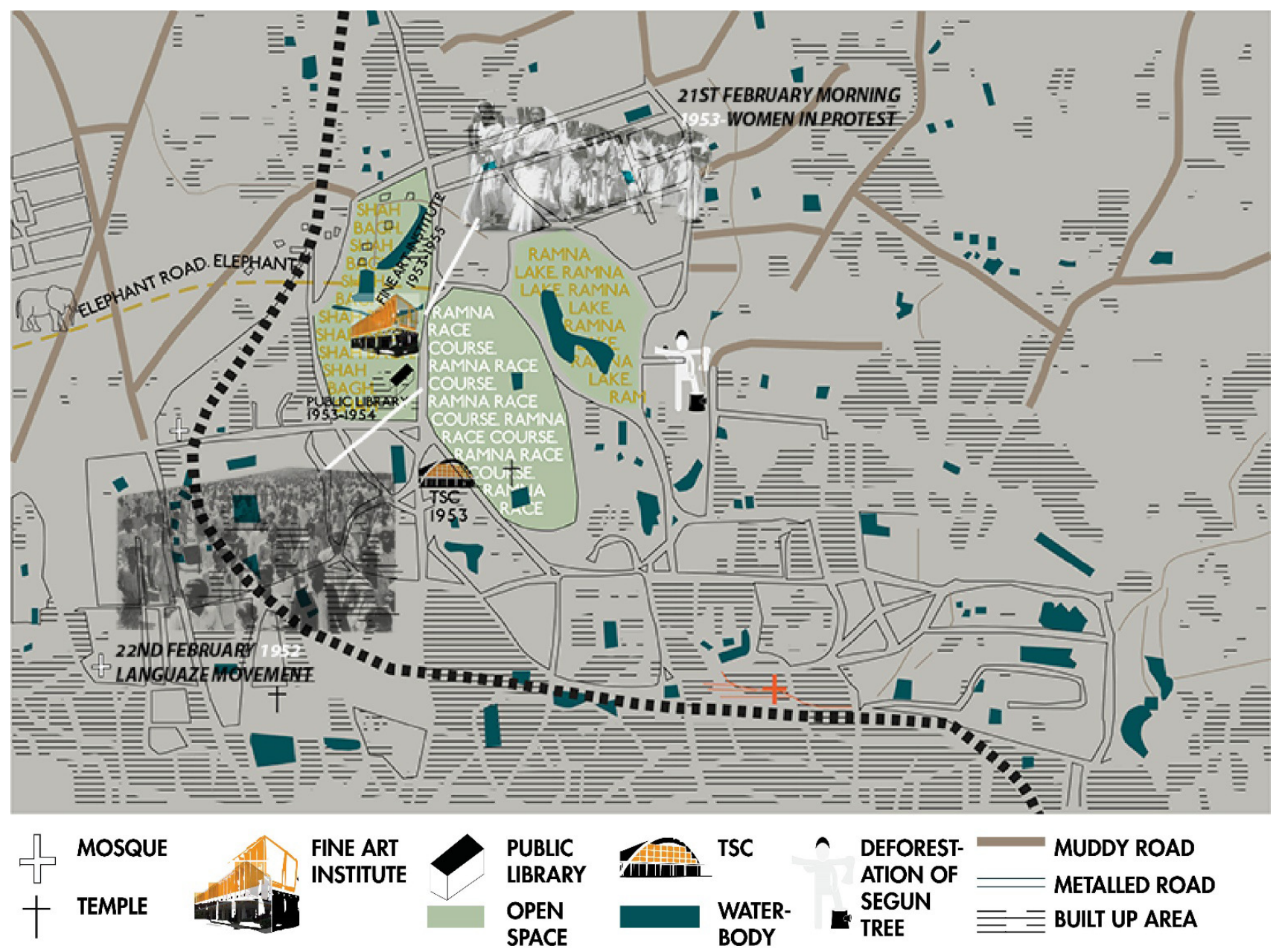

Figure 5. Bengali modernist architecture made the avenue a strong ground for protest. Figure developed by author Salma Begum. 
Khan Avenue responded to different modernist conceptions that started with the 1952's language movement.

Due to the riots and disputes against the Pakistani political regime to attain Bangla as one of Pakistan's state languages, 1952 was a historic milestone. This period was also significant for the feminist history of Bangladesh due to the women's presence in the language movement (Figure 5) at Dhaka University premises. When the West Pakistani government-imposed Urdu as the only official language of Pakistan, the protesters flouted section 144 by assembling at the Amtala site in Dhaka University campus and joined the movement on the right to speak their mother tongue. Thus, Dhaka University premises were chosen as a protest ground to demand equal status for their native languageBangla. The female students went out in the morning of 21 February 1952 to gather girls' participants from different schools in Dhaka and proceed to the procession from Amtala (Babul, 2014; "The forgotten women veterans," 2007). Among the protesters, twelve females stood out due to their rebellious activities-Halima Khatun, Dr. Sufia Khatun, Rawshan Ara Bachchu, Sufia Ibrahim, Fazilatunnessa, Rani Bhattachariya, Pratibha Mutsuddi, Sofia Khan, Zulekha, Nuri, Sara Taifur, Sufia Ahmed, and Safia Khatun (Babul, 2014). These women first came out to the streets during curfew, broke Section 144, evaded the police barricades, and gathered at the Amtala site in Dhaka University campus to join the movement (Babul, 2014).

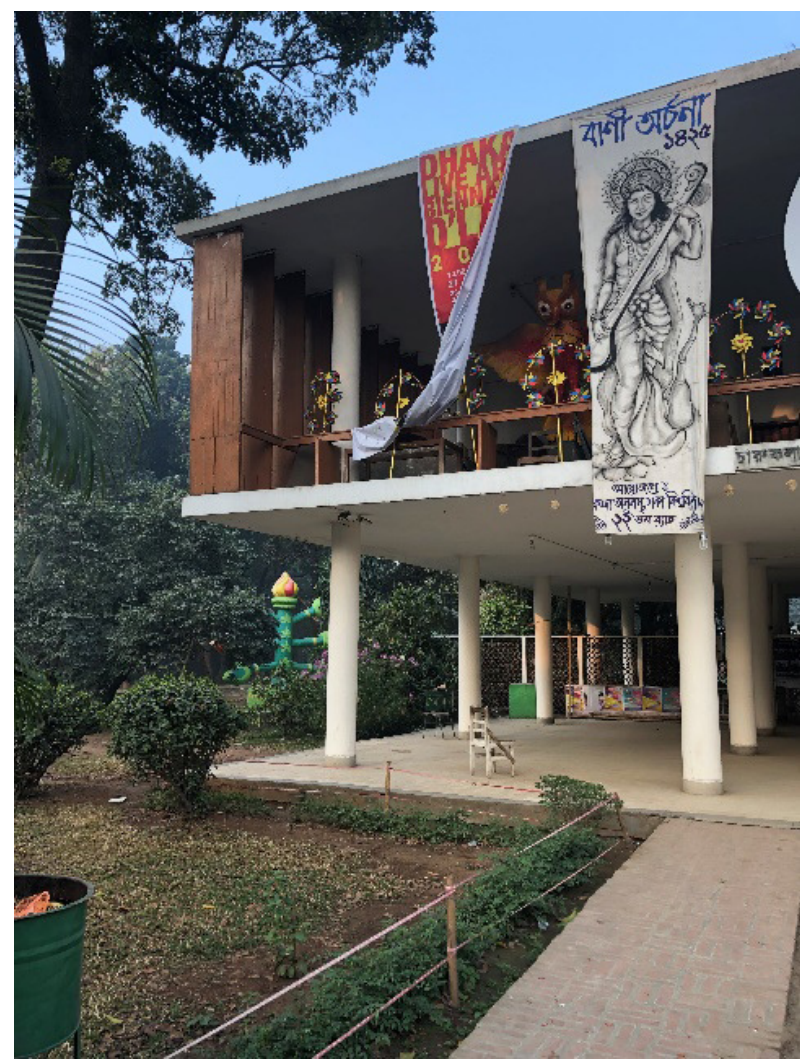

Figure 6. Fine Art Institute symbolizing modernism in Bengal. Photograph taken by author Salma Begum, 2019.
Incidents of harassment were reported, and multiple women were arrested. When police opened fire on protesters, several students and participants were killed, injured, and thousands were arrested. A small monument called Shahid Minar was erected as a memorial immediately afterwards at the premises (Habib, 2010). The involvement of women can be testified by Rawshan Ara Bachchu's interview published as a news article, where she spoke about the participation of women in the language movement:

In the then conservative society, it was not at all easy for women to directly participate in such a movement. The university's female students had to pay Rs 10 as a fine for talking to any male student without the proctor's permission. The number of girl students in Dhaka University was 40 to 50 - of them, 25 to 30 remained in the hall. About four of us secretly joined student meetings after class or during recess. ("The forgotten women veterans," 2007, para. 3)

The movement gained momentum, and after long struggles, Bangla was given equal status as Urdu (Uddin, 2006). Soon after independence, in 1973, the monument was rebuilt by the state's Public Works Department, which led to the emergence of the Shahid Minar Plaza and its institutional surroundings as "pre-eminent symbolic space of Dhaka to organize demonstrations, broach condemnation and denounce cultural assertion" (Habib, 2010, p. 12). This way, a prominent testament to popular protest was engrained in the site's materiality, as a minor reference to a significant layer of gender-based contestation and revolt.

\subsubsection{An Avenue of Contestation in Pre- and Post-Liberation Time (1965-1975)}

Over time, urbanization started to take over, domesticating the landscape of Shahbag. Figure 7 depicts the Shahbag area as a palimpsest of urbanization, political riots, cultural events, and women's role in the independence war. After the 1960s, urbanization reached its apogee. Profound changes were evident both in the infrastructure and morphology of green space. The muddy roads from 1952 eventually turned into concrete roads (Figure 7). The connection for the elephants between Shahbag and Pilkhana transformed into a vehicular road that intersected the road where Ramna racecourse was located, creating a central node in the city. This node can be defined as the beginning of the Shahbag Chattwar (ground of protest). As railway tracks shifted eastward in the mid-60s, the old rail tracks were converted into a wide avenue that became the principal axis between the old and new Dhaka. From 1961 onwards, the place started to host diverse events (Figure 7), such as congregations, festivities, marches, etc.

Bengali culture holds a special place for celebration, evident in different festivities. The first day of the Bengali 


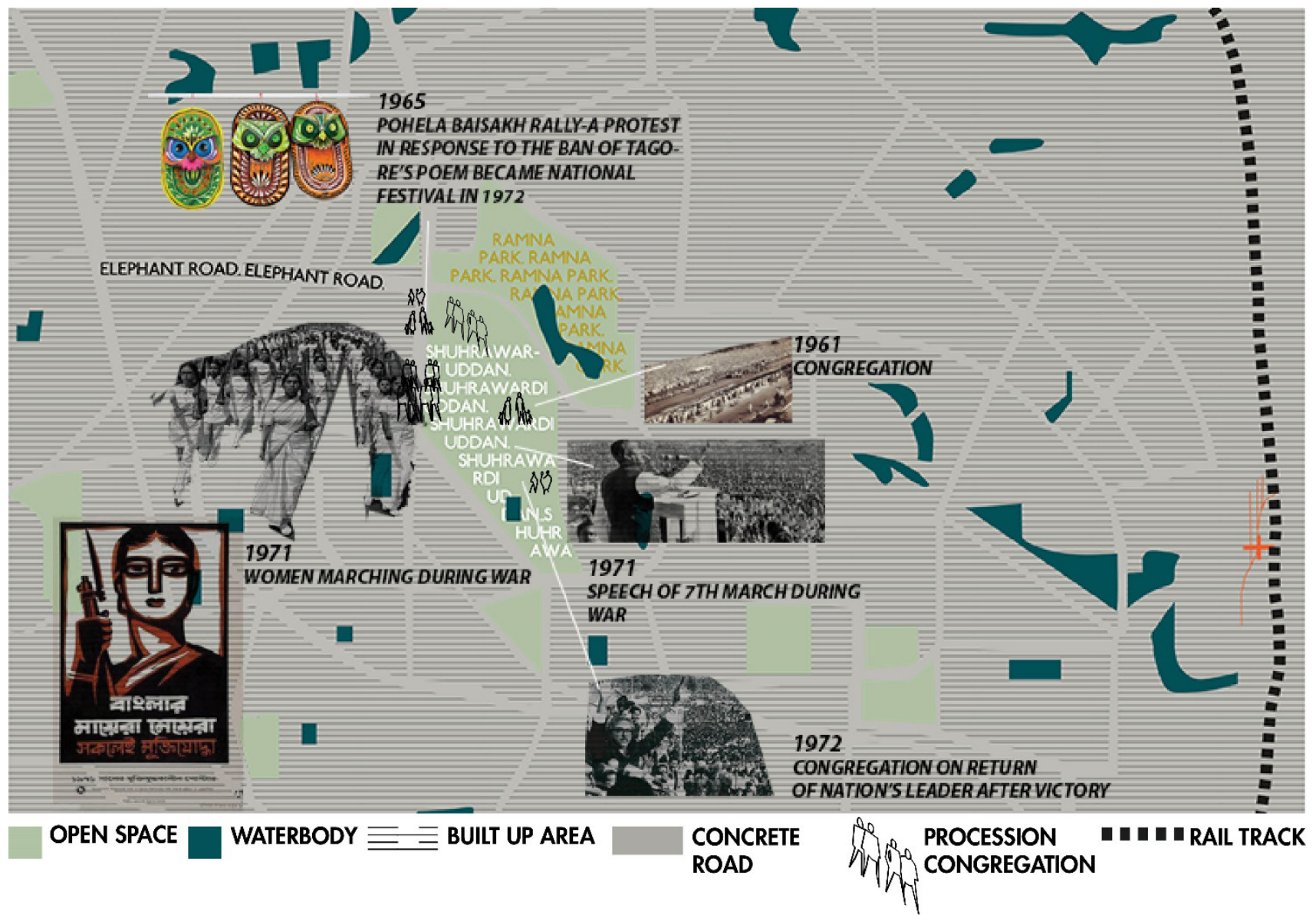

Figure 7. Pre- and post-liberation Shahbag urbanization takes over the landscape in 1975 . Figure developed by author Salma Begum.

new year (Pohela Baisakh) begins its celebration with a rally titled "Mongol Sova Jatra" on the street of Shahbag. The day has a symbolic meaning to Bengali people and holds ample significance in view of national identity (Samayeen \& Imon, 2016). This specific event from 1965 is a place-bound festival rooted in its cultural landscape. The Pohela Baisakh emerged as a response to Bengali culture's suppression (Habib, 2010). The protest became a national festival in 1972. From 2016, it became recognized by UNESCO as intangible cultural heritage of humanity.

Additionally, Shahbag street appeared to be a ground of objection during the liberation war in 1971, when women were seen taking part in the marching. Moreover, the Ramna racecourse became a prime site for political movements-primarily known for the Nation's Father Bangabandhu Sheikh Mujibur Rahman's historic speech on 7 March 1971. It was a call to nationwide people to fight for the language where the oath for independence was declared in front of a large swath of Bengali (Habib, 2010). Both Bengali men and women of diverse classes, caste, religion, and ethnic backgrounds responded to the call of Sheikh Mujib.

Nonetheless, one of the most significant shortcomings in the perception of the fight for independence is the consistent failure to recognize the role of women in the Liberation War. In fact, women's role was largely ignored, denied, and misconstrued in Dhaka's mainstream history (Babul, 2014; Saikia, 2011). So-called war heroes should have included those women who supported the valiant freedom fighters with food, shelter, funds, as well as nursed the wounded and hid weapons risking their own lives. Acknowledgement should have also been made to those who had willingly sent their sons to war, who have lost their loved ones and, even worse, been subjected to sexual abuse and survived to bear the scar. The poster in 1971 with the writing Banglar mayera, meyera, sokolei muktijoddha ("mothers and daughters, all of them are freedom fighters of Bangladesh") testified of this significant women engagement in the war (the poster can be found at Dhaka Museum; see Habib et al., 2014, p. 75)

Ramna was appropriated again on 16 December 1971 by the Pakistan Military Forces to surrender. This multifaceted Ramna green space was renamed Shuhrawardin Uddan after independence in 1971. This place also witnessed the mass-gathering for the return of Bangabandhu Sheikh Mujib after independence.

\subsection{A Chattwar of Rights to Public Space From 1997 Onwards}

The Shahbag area re-surfaced as a ground of contestation organically in many different names under different 
political powers: from Mughal pleasure garden to civil station, racecourse maidan to Shuhrawardi Uddan, from Ayub Khan Avenue in 1952 to present Shahbag Chattwar. In the post-independence period, the Ramna racecourse was divided into two segments: the Shishu park area and Shuhrawardi Uddan area.

In 1990, Shahbag Chattwar and the south of Shuhrawardi Uddan occupying the Dhaka University area, arts building, Teacher-Student Centre, and Fular Road witnessed the democratic movement in 1990. The 1990s movement, on the one hand, worked for the restoration of democracy; on the other, it energized the feminist and women movement in Bangladesh towards a democratic transition (Nazneen, 2013). Women and feminist activists claimed their platform to negotiate with different stakeholders, including the state, to protect gender rights in Bangladesh (Nazneen, 2013, 2017; Nazneen \& Sultan, 2014). Besides, the area concentrated many other resistance movements, such as the movement against the Caretaker Government (known as 1/11) of 2007-2009, the Shahbag movement of 2013, the Road Safety Protest of 2018, and the anti-rape movement of 2020.

The corresponding architectural developments and art installations on the site highly shaped the morphogenesis of the Shahbag area. The Raju Bhashkorjo (Figures 8 and 9) is one of the most influential sculptures that sym- bolized the anti-terror movement from 1992. It was built in the memory of Moin Hossain Raju, an activist of the Bangladesh Chatra Union. The sculpture sits at the exact location where he was gunned down on 13 March 1992 while protesting student terrorism at Dhaka University campus. Since then, this point has acted as a highly symbolic ground for student protests. Moreover, Raju Bhashkorjo (Figures 8 and 9) and the sculpture in Shahbag Chattwar form an axis (Figure 9) that holds multicultural functionality during protest rallies.

Every year in February, the national book fair Amar Ekushey Grantha Mela ("immortal book fair of the twenty-first") occupies the whole avenue. This book fair is dedicated to the martyrs who died on 21 February 1952 during the language movement. Festivities in the name of the cultural rally, the first day of Spring of Bengali month Falgun (the Pohela Falgun), the book fair, and the Dhaka Literary Festival happen to be choreographed in different forms with different colors in the Shahbag area. One of the critical movements that made it iconic was the Shahbag movement of 2013. This movement, also known as Gonojagoron Moncho, started on 5 February 2013 to protest against a verdict on war criminals. It was the largest mass demonstration since 1990.

The Shahbag movement started against Jamaati-Islam leader Abdul Quader Molla's verdict by the International Crimes Tribunal, who was sentenced to life

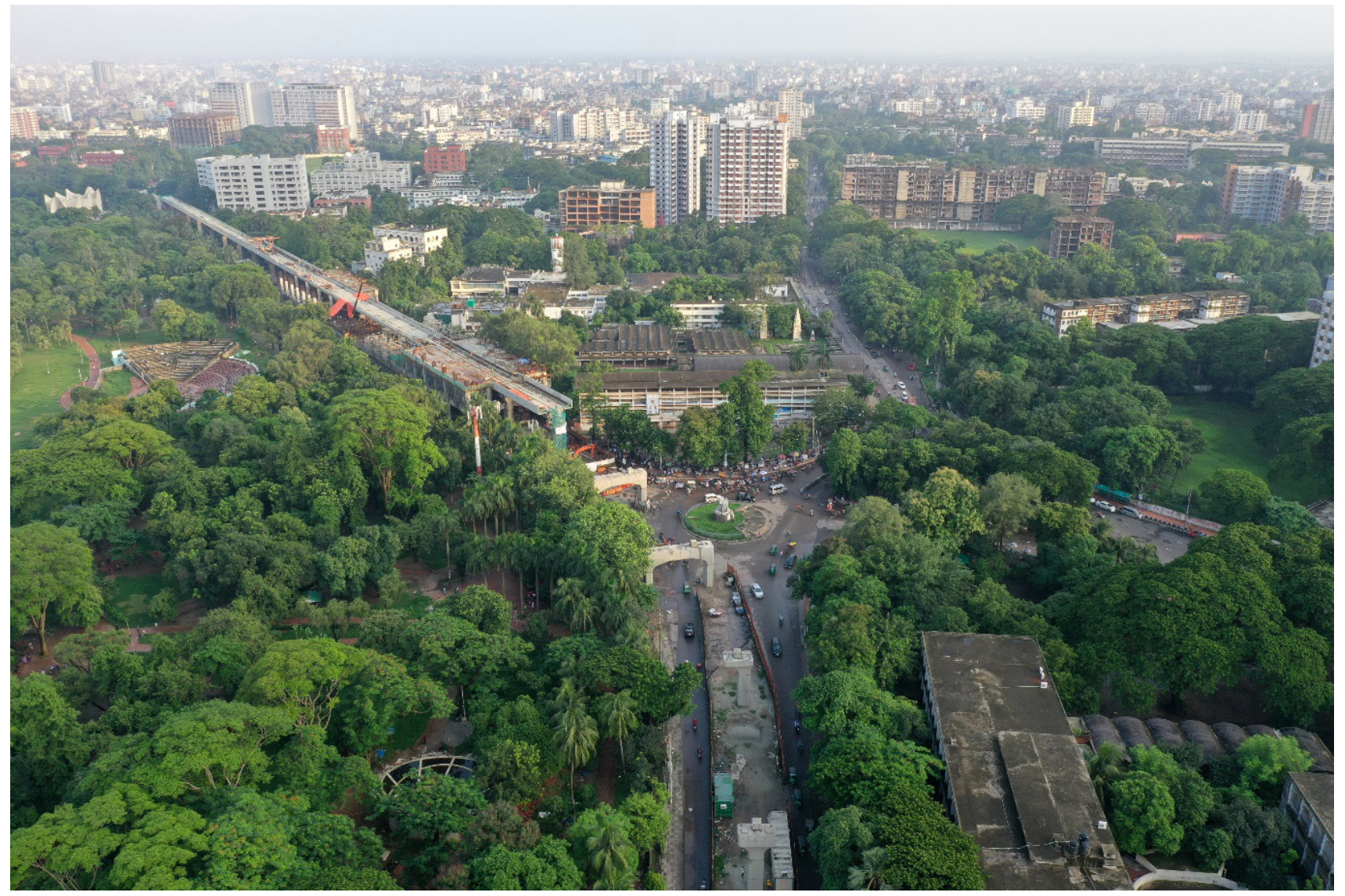

Figure 8. Raju Bhaskarjo, the epitome of protest and testimony of the recent metro rail intervention. Photograph by Huda, 2021. 


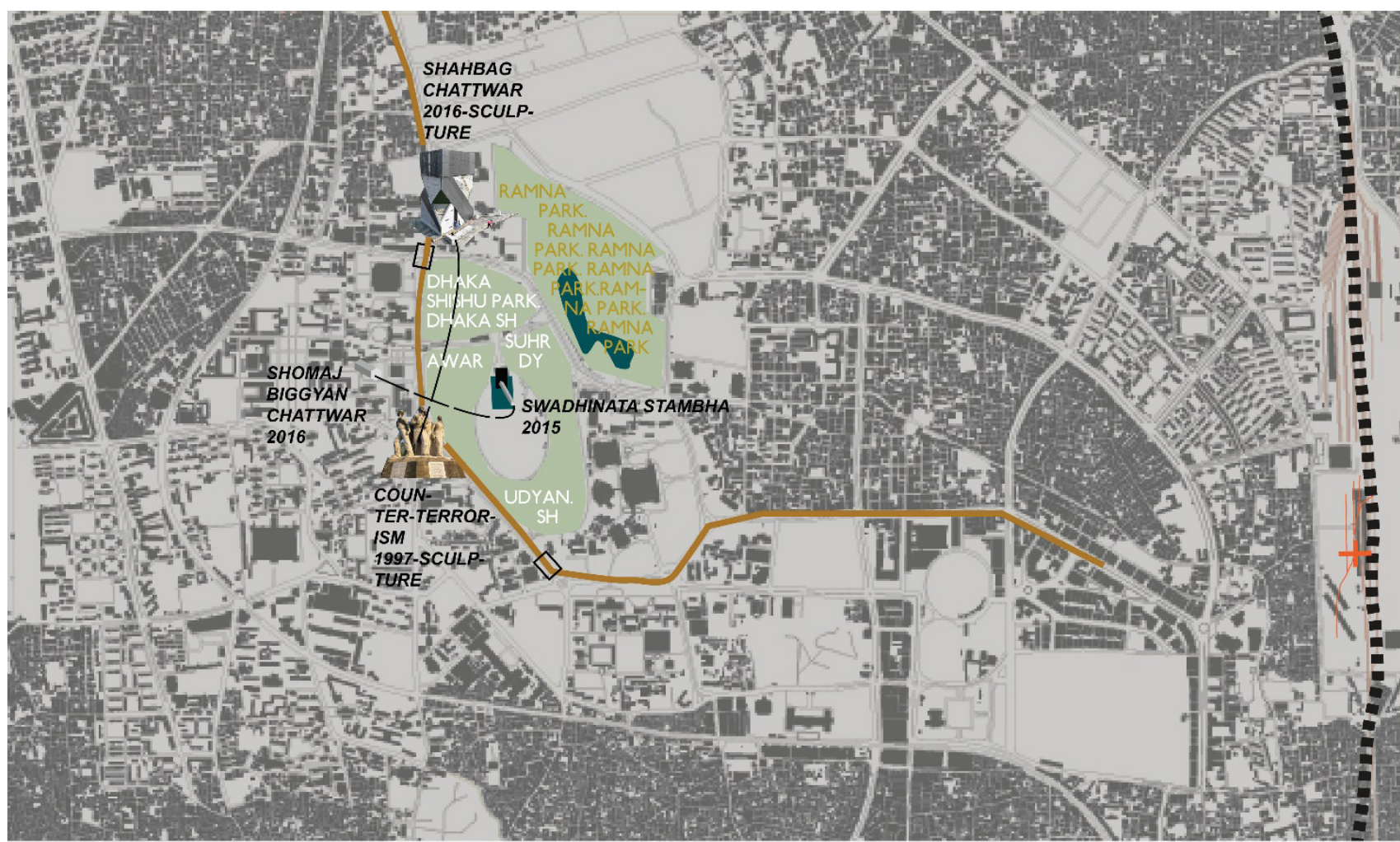

GREEN SPACE

SHOMAJ BIGGYAN CHATTWAR
WATERBODY " RAIL TRACK

SWADHINOTA STAMBHA

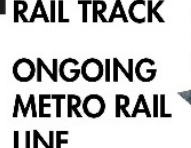

LINE
SHAHBAG CHATTWAR SCULPTURE

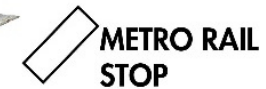

RAJU BHASHKORJO

Figure 9. Present-day map showing recent design intervention and infrastructure in Shahbag area, Shahbag protest movements, and art sculptures. Figure developed by author Salma Begum.

in prison for his crime against humanity. Following the ruling, a group of online activists and bloggers started the protest at Shahbag and demanded the death sentence of Quader Molla. This youth-led movement also encouraged the people of Bangladesh to believe in the spirit of the Liberation War. Such a movement also spread the feeling that they were fighting another war against the same enemies/war criminals who killed three million people and dishonored about half a million Bangladeshi women during the liberation war in 1971. However, the Shahbag movement was challenged by Islamist political parties, such as Jamati-Islami and Hefazot-e-Islam. There were attempts to brand the Shahbag movement as an "anti-Islamic" gathering initiated by atheist bloggers. On 5 May 2013, thousands of activists of Hefazate-Islam gathered in Dhaka and demanded 13 points, including the death penalty of the atheist bloggers, and a ban on the mixing of men and women in public space. Despite the challenges by Islamist fundamentalists, the Shahbag movement embodied a new dimension in Dhaka's history by female activists' participation. Lucky Akter's (one of the female front-line faces in Shahbag) slogans encouraged all the participants to join the movement at Shahbag.
Nonetheless, many female protestants were threatened to be raped and repeatedly harassed, and fear and tension riddled the protests. Despite these challenges, Shahbag became a protected arena for the female protestors, in part, safeguarded by supportive male co-protestants. This remarkable mobilization also furthered women's involvement in other form of activisms and protests, such as the Road Safety Protest in 2018 and anti-rape movement in 2020.

Women's presence and involvement in the Shahbag movement faced two significant challenges: criticism of women's "westernized" agenda and tackling the Islamic fundamentalist political party. Criticism of women protester's "westernized" agenda in Bangladesh is often regarded as a threat to Bangladesh's cultural and religious norms (Nazneen \& Sultan, 2014). Such criticism was triggered during the Shahbag movement for women wearing western attire without purdah (veil). However, the critics overlooked the presence of a significant number of women with Hijab (following purdah) and Shari (traditional Bengali woman's attire). This gendered notion reintroduced women with two different clusterswomen with "modest" attire as ideal and women with "western" attire as the opposite, adding an intersectional 
layer of identity that complexifies gender-divisions in the formation and contestation of identities in public space.

The second challenge was the proposition by Hefazate-Islami (a rising Islamic party consisting of Islamic school students). The proposal demanded to ban the mixing of men and women in public space. In response to these criticisms, secular protestants presented women protestants as "asexual" (as sister and mother figures), devoid of any further identity. In line with that, women's presence in the protest was justified either as "virtue" (evidenced by the Shahbag movement) or as a victim (evidenced by the anti-rape movement). This trend also continues in the representation of women in art, design and sculpture in the Dhaka University campus and its surroundings. In these forms of arts, design and sculpture, women's images could usually not transcend more traditional gender roles.

After the Shahbag movement, in 2016, the Shuhrawardi Uddan saw a new architectural endeavor (Figure 8), the Shadhinata Stambaha ("freedom monument"), in commemoration of 7 March historic speech by Seikh Mujibur Rahman. The museum plaza and glass tower are the new ground for the celebration of Independence Day, and in 2021, the book fair was organized in this precinct of Shuhrawardi uddan. Another small scale Chattwar was built in the same year opposite to the museum across the Shahbag Road behind the central library, next to the historic Madhur Canteen.
The area remained unattended for years, and from 2016 onwards, it acts as a small hub for student gatherings. The city people currently appropriate the Shomaj Biggyan Chattwar (social science plaza) along with the Dhaka University students. The Shahbag area is now a constellation of public spaces which has historical and symbolic importance. The contestation is an everyday reality for the Shahbag area, and protests continue to add to its symbolic and political importance. Recent protests from 2020 testify to the nature of the movements in Raju Bhashkorjo. Dhaka University Hindu students protested and went on a hunger strike in response to Dhaka Mayoral poll on Saraswati PujaDay. Students also opposed the mass rapid transit line-6 (MRT Line-6) planned through the Dhaka University campus during the Covid-19 outbreak. The protest against MRT Line- 6 (Figure 10) passing through the Shahbag area culminated with the submission of a memorandum to the vicechancellor of Dhaka University demanding the relocation of the rail track. This protest was significant because the implementation of MRT Line- 6 will not only destroy the educational environment of Dhaka University in the Shahbag area, but also the cultural landscape, which is part of significant events such as the Pohela Baisakh celebration and the Pohela Falgun, as well as Amar Ekushey Grantha Mela, the biggest book fair of the country. The aftermath of the changing ecology is already visible from the ongoing construction scene.

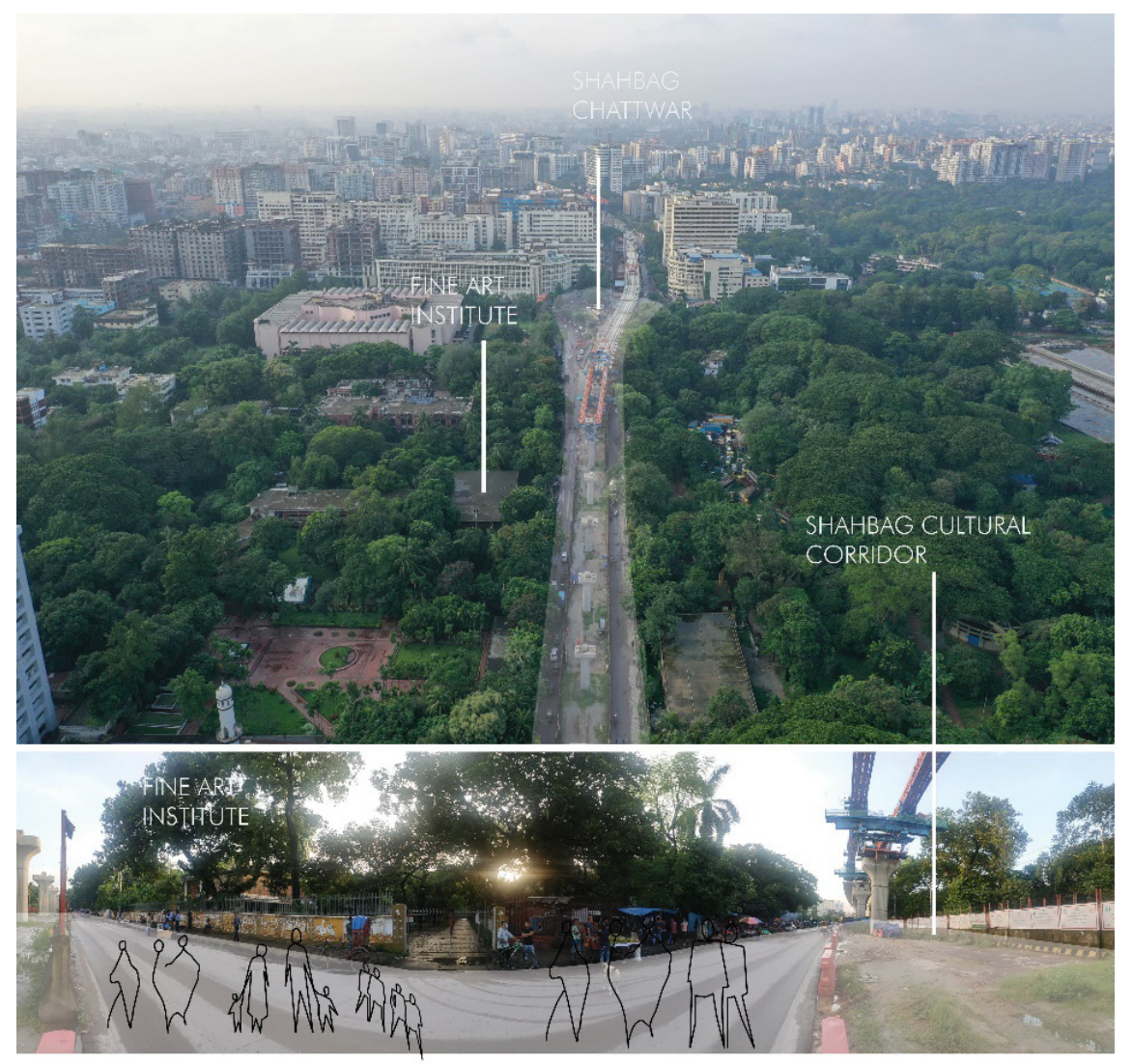

Figure 10. Infrastructure destroying the Shahbag cultural corridor and plaza. Figure developed by author Salma Begum based on photographs by Huda in 2021. 
Like the Agora, the Shahbag provided the space to claim political rights to the city, people, and place. Art and design in the Shahbag area promoted and celebrated the arena as a ground of protest and contestation and imbued it with a distinct place-bound identity. The non-human, or material agency of the particular place, its historical location in the city, and the multiple architectural and sculptural objects that compose its physical form played a crucial role in this process, and inherently interacted with vast popular mobilizations. However, recent infrastructural interventions against which the students recently protested are transforming the character of the place and poses a threat to the cultural landscape of Shahbag. With this metro rail project passing through the Shahbag corridor, which has already started to change the physicality of the place, the pandemic of 2021 is most notably about to add a brutal scar to the palimpsestic history of the site.

\section{Conclusion}

Feminists have been claiming women's rights to the city since the last few decades by identifying material barriers that women disproportionately encounter. Feminist and city debates evolve on how the city represents and nurtures the unequal and gendered ways of maintaining society across gender, race, sexuality, class, and ability (Kern, 2020). In line with that, the Shahbag case study demonstrates the particular role of women's involvement in different movements and protests and how their presence in public space has been challenged, negotiated and renegotiated, shaped and re-shaped across the years within Islamist and secular political space.

Bangladesh's secular-minded society appreciated women's protests in different movements starting from the 1952 language movement, the liberation war in 1971, the 90s democratic movement, and finally, the Shahbag movement in 2013. But women's participation in these movements yielded threats and harassment. As a result, there was a constant fear and tension among them. Such fear consists of three types: (a) the danger of being raped, (b) the threat of harassment by the opposition, and (c) the loss of their "honor" by being assaulted. Reports of sexual assaults during the Pohela Boishakh celebration in 2015 and sexual harassment in the New Year celebration night in 2013 strengthened the fear. Tension also arose from a bomb blast at Ramna Batamul during the Pohela Boishak celebration of 2001, equally valid for both women and other secular-minded people. Over the last few decades, these events created social opposition among people, such as men vs. women, rajakar (traitor) vs. patriots, traditional vs. western, Islamic vs. non-Islamic, secularism vs. fundamentalism, etc.

A notorious dimension of gender and public space discussions in Bangladesh denoted that women came out in public space when the state or community needed them to do that, but under the supervision and protection of males. Men have historically dominated pub- lic space. However, women were "needed" when the state required them as key economic enablers. Today, Bangladesh is the second-largest textile-producing country globally, employing millions of people, of which a large percentage are women. Like the economy, in different movements and protests, women-only came to the foreground when men needed women to strengthen their power.

Nonetheless, public space so far did not ensure women's safety and failed to offer an inclusive and fearless space. Men still needed to protect women's safety during the movements. In a sense, therefore, men's role as guardians, leaders, dominant influencers, guides, and protectors has not changed much. Women's voices often remain unheard due to men's authoritarian dominance. The construction of hegemonic masculinity was the reason behind women's subordinate position. This type of construction of masculinity influences men to conduct violence against women to show their power and superior authority.

Although many feminists seem optimistic about female protesters' roles during Shahbag and anti-rape movements, the fear of violence still exists. The safety, security, and inclusion of women in public space become the primary concern, whereas the "rights" of women are still undefined and often remain gendered. The gender dynamics are closely bound up with the changing materiality of Dhaka's public space. This article unraveled some of these diversified events that drastically changed the public space landscape as an ever rewritten and partly erased palimpsest. In such light, the cultural landscape of Shahbag can be seen as a palimpsestic juxtaposition of ecological, social, political, and gendered cultural layers. At present, Shahbag continues to be Dhaka's prime site for political riots and cultural events. Each of the events has contributed to the specific and contested character of this contemporary site. Architectural and urban design and art, as much as popular forms of protest and resistance, thus forged a remarkably "gendered" space that continues to play a crucial role in the city's further development of inclusion and social rights.

\section{Acknowledgments}

We would like to thank Prof. Bruno De Meulder for his invaluable feedback throughout the PhD process. Furthermore, we express our sincere admiration to the reviewers and editors for their valuable comments. Moreover, we would like to offer our gratitude to both the Government of the People's Republic of Bangladesh for the Prime Minister Fellowship and the Interfaculty Council for Development Co-Operation (IRO) at KU Leuven for sponsoring our PhD researches. Finally, we would like to thank Mr. Huda for his support with the photographs.

\section{Conflict of Interests}

The authors declare no conflict of interests. 


\section{References}

Babul, P. (2014, December 2). Women's role in '52, '71. The Daily Star. https://www.thedailystar.net/ womens-role-in-52-71-shahbagh-53033

Beebeejaun, Y. (2017). Gender, urban space, and the right to everyday life. Journal of Urban Affairs, 39(3), 323-334. https://doi.org/10.1080/07352166. 2016.1255526

Begum, S. (2018). Changing scenarios of public open space in a British colonial city. Nakhara Journal of Environmental Design and Planning, 14, 39-56. https://ph01.tci-thaijo.org/index.php/nakhara/ article/view/104338

Begum, S. (2020). Reclaiming public open space within the shifting landscape of Dhaka, Bangladesh. Civil Engineering and Architecture, 8(6), 1178-1193. https://doi.org/10.13189/cea.2020.080603

Bondi, L. (1998). Gender, class, and urban space: Public and private space in contemporary urban landscapes. Urban Geography, 19(2), 160-185. https://doi.org/ 10.2747/0272-3638.19.2.160

Chant, S., \& Mcllwaine, C. (2016). Cities, slums and gender in the global south: Towards a feminised urban future. Routledge.

Collins, P. H. (1990). Black feminist thought knowledge, consciousness, and the politics of empowerment. Routledge.

Collins, P. H., \& Bilge, S. (2016). Intersectionality. Polity Press.

Constitution of the People's Republic of Bangladesh, 1972. https://www.refworld.org/docid/3ae6b5684.html

Corboz, A. (1983). The land as palimpsest. SAGE Journals, 31(121), 12-34. https://doi-org.kuleuven.ezproxy. kuleuven.be/10.1177/039219218303112102

Crenshaw, K. (1989). Demarginalizing the intersection of race and sex: Black feminist critique of antidiscrimination doctrine, feminist theory and antiracist politics. University of Chicago Legal Forum, 1989(1), 139-167. https://chicagounbound.uchicago.edu/cgi/ viewcontent.cgi?article $=1052 \&$ context $=$ uclf

Crenshaw, K. (1991). Mapping the margins: Intersectionality, identity politics, and violence against women of color. Stanford Law Review, 43(6), 1241-1299. https://doi.org/doi:10.2307/1229039

Doshi, S. (2017). Embodied urban political ecology: Five propositions. Area, 49(1), 125-128. https://doi.org/ doi:10.1111/area.12293

Habib, K. (2010). The post colonial public spaces and its cultural diversity: The case of national-cultural representative public spaces of Dhaka. In Assessing and exploring the state of urban knowledge (pp. 89-109). N-AERUS.

Habib, K., Heynen, H., \& De Meulder, B. (2014). (Un)Covering the face of Dhaka: Gender politics and public space in the post-colonial city. Environment, Space, Place, 6(2), 69-98. https://doi.org/10.5840/ esplace20146212
Kern, L. (2020). Feminist city: Claiming space in a manmade world. Verso.

Lal, R. (2003). Rethinking Mughal India: Challenge of a princess' memoir. Economic and Political Weekly, 38(1), 53-65. https://www.jstor.org/stable/4413046

Nazneen, S. (2013). Men aboard? movement for a uniform family code in Bangladesh. In M. Al-Sharmani (Ed.), Feminist activism, women's rights and legal reform (pp. 101-124). Zed Books.

Nazneen, S. (2017). Negotiating gender equity in a clientelist state: The role of informal networks. In G. Waylen (Ed.), Gender and informal institutions (pp. 161-181). Rowan \& Littlefield.

Nazneen, S., \& Sultan, M. (Eds.). (2014). Voicing demands: Feminist activism in transitional contexts. Bloomsbury Publishing.

Nightingale, A. J. (2011). Bounding difference: Intersectionality and the material production of gender, caste, class and environment in Nepal. Geoforum, 42, 153-162. https://doi.org/10.1016/j.geoforum.2010. 03.004

Panday, P. K. (2008). Representation without participation: Quotas for women in Bangladesh. International Political Science Review, 29(4), 489-512. https://doi. org/10.1177/0192512108095724

Peake, L. (2016). The twenty-first-century quest for feminism and the global urban. International Journal of Urban and Regional Research, 40(1), 219-227. https://doi.org/doi:10.1111/1468-2427.12276

Saikia, Y. (2011). Women, war, and the making of Bangladesh: Remembering 1971. Duke University Press.

Salehin, M. M. (2018). Islamic NGOs in Bangladesh development, piety and neoliberal governmentality. Routledge.

Samayeen, N., \& Imon, S. S. (2016). The cultural landscape of the Pohela Boisakh festival and the making of a social identity in Bangladesh. In K. Silva \& A. Sinha (Eds.), Cultural landscapes of South Asia (pp. 159-170). Routledge.

Siddiqua, F. Z. (2017, January 27). Blast from the past. The Daily Star. https://www.thedailystar.net/starweekend/blast-the-past-1351450

Sultana, F. (2020). Embodied intersectionalities of urban citizenship: Water, infrastructure, and gender in the global south. Annals of the American Association of Geographers, 110(5), 1407-1424. https://doi.org/ $10.1080 / 24694452.2020 .1715193$

The forgotten women veterans of the language movement. (2007, February 24). Bdnews24. https:// bdnews24.com/bangladesh/2007/02/24/theforgotten-women-veterans-of-the-languagemovement

Uddin, S. M. (2006). Constructing Bangladesh: Religion, ethnicity, and language in an Islamic nation. University of North Carolina Press.

White, S. C. (2012). Beyond the paradox: Religion, family and modernity in contemporary Bangladesh. Mod- 
ern Asian Studies, 46(5), 1429-1458. https://doi.org/ $10.1017 /$ S0026749X12000133

Yuval-Davis, N. (2006). Intersectionality and feminist politics. European Journal of Women's Studies, 13(3), 193-209. https://doi.org/10.1177/135050680 6065752

\section{About the Authors}
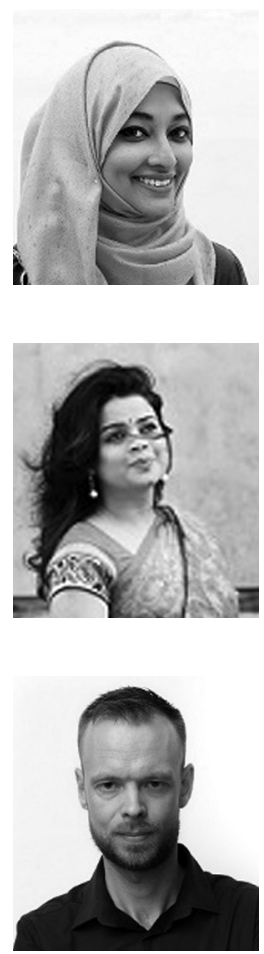

Salma Begum is an independently practicing Bangladeshi architect and faculty member at Ahsanullah University of Science and Technology, Dhaka, Bangladesh. Currently, she is pursuing her PhD as part of the OSA Research Group at KU Leuven, Belgium, funded by the Prime Minister Fellowship of the Bangladesh Government. Her current research aims to develop an instrumental basis for public open space development related to water impacts through cartographic exploration for Dhaka. She frequently contributes to international architectural publications. Based on her PhD research, one of her international conference papers got awarded the Best Paper Award in 2020.

Jinat Hossain is a PhD scholar in the Division of Geography and Tourism, Department of Earth and Environmental Sciences at KU Leuven, Belgium. Her PhD work is on climate change, gender, and social innovation, and her interest covers multi-disciplinary issues connected to gender and feminist theories. Some of the themes she is working on are gendered space, land rights, migration, religion, the gendered body, sexuality, and masculinity. She is also an assistant professor at Noakhali Science and Technology University, Bangladesh.

Jeroen Stevens is an architect and urbanist, currently engaged as a post-doctoral researcher in the OSA Research Group at KU Leuven and as Fulbright \& BAEF visiting scholar at Columbia University, New York. His research sounds out the particular agency of urban movements as they struggle for more socially just cities. Drawing from immersive engagement in complex metropolitan environments, his work dwells on the nexus of urbanism and urban anthropology. 